Institution of Mining and Metallurgy, will take place. There will be four sessions, the first two dealing with medical aspects, and the third and fourth with dust sampling and control. There is no fee for attending the Conference; a volume of proceedings will be published as soon as possible after the meeting. Particulars can be obtained from either of the organising Institutions, Salisbury House, Finsbury Circus, London, E.C.2.

\section{German Scientific Periodicals}

WE have received a list of ninety German scientific periodicals for which permission to begin publishing has been obtained from the Control Commission. About a quarter of these have already been started. Among them are a number of journals which existed before the War, such as Die Naturwissenschaften, published with Prof. A. Eucken of Göttingen as editor, Metallforschung under Prof. Masing's direction, and also a considerable number of medical journals. Messrs. Springer intend to restart Zeitschrift für Physik; but this apparently has not yet begun. A new journal containing interesting articles by a number of well-known physicists is Zeitschrift für Naturforschung, published by Dieterich'sche Verlagsbuchhandlung, Wiesbaden (see Nature, Sept. 14, p. 372).

\section{Association of British Zoologists}

Ax the annual meeting of the Association of British Zoologists held in the rooms of the Zoological Society on January 11, the following were elected officers and new members of the council for the year 1947-48: President, Dr. Edward Hindle; Hon. Secretary, Dr. D. L. Gunn, Anti-Locust Research Centre, British Museum (Natural History), Cromwell Road, London, S.W.7 ; Hon. Treasurer, Dr. A. G. Hamilton, Royal Veterinary College, Royal College Street, London, N.W.1 ; New Members of Council, Prof. H. Gordon Jackson (re-elected under provisions of the constitution), Prof. C. M. Yonge, Dr. J. W. Evans, Dr. A. Graham and Mr. G. P. Wells. A discussion on "Careers in Zoology-Possibilities and Training" took place, an account of which is reported on page 378 of this issue of Nature.

\section{Royal Society of Edinburgh : New Fellows}

THe following have been elected fellows of the Royal Society of Edinburgh: Mr. F. W. Anderson, senior geologist, H.M. Geological Survey, palæontologist in Scotland, Edinburgh; Dr. J. G. C. Anderson, senior geologist, H.M. Geological Survey, Edinburgh; Dr. R. N. Arnold, regius professor of engineering, University of Edinburgh; $\mathrm{Mr}$. Hamilton Bailey, Denham, Totteridge, London, N.20 ; Dr. G. H. Bell, senior lecturer in physiology, University of Glasgow; Dr. W. P. Blount, poultry adviser to Unilever Group, Stoke Mandeville, Bucks; Dr. N. L. Bor, Forest Research Institute, Dehra Dun; Dr. L. M. Brown, lecturer in technical mathematics, University of Edinburgh; Dr. W. F. Cassie, professor of civil engineering, King's College, University of Durham; Dr. S. C. Curran, lecturer in natural philosophy, University of Glasgow; Dr. J. H. Fraser, member of scientific staff, Marine Laboratory, Aberdeen; Prof. Tom Grahame, Anatomy Department, Royal (Dick) Veterinary College, Edinburgh; Dr. G. Heslop Harrison, University of Durham; Dr. J. A. Hewitt, senior lecturer in physiology, King's College, University of London;
Dr. J. M. Hyslop, lecturer in mathematics, University of Glasgow ; Dr. J. M. Jackson, lecturer in mathematics, University College, Dundee; Dr. Otto Löwenstein, lecturer in zoology, University of Glasgow; Dr. A. J. Macintyre, lecturer in mathematics, University of Aberdeen; Group Captain G. S. Marshall; Dr. James Reekie, lecturer in physics and Carnegie Teaching Fellow, University of St. Andrews; Mr. J. M. Muirhead, manager, Scottish Provident Institution, Edinburgh; Mr. W. H. Senior, assistant secretary, Department of Agriculture for Scotland, Edinburgh; Dr. A. K. M. Trivedi, professor of chemistry, Lingraj College, Belgaum, India; Dr. G. R. Tudhope, lecturer in pathology, University of St. Andrews, and pathologist, Royal Infirmary, Dundee; Dr. B. Woolf, lecturer in vital statistics, Department of Public Health, University of Edinburgh.

\section{Announcements}

The Council of the Royal Society of Edinburgh has awarded the Makdougall-Brisbane prize for the period 1944-46 to Dr. William Black, of the Scottish Society for Research in Plant Breeding, for his work dealing with genetical investigations on the potato, with their practical applications.

THE Textile Institute has awarded a scholarship, offered under the terms of a grant from the Cotton Trade War Memorial Fund (total value £750, tenure three years), to George H. Ewins, a cotton-spinning student at Bolton Municipal Technical College, who will now proceed to a university degree course.

Dr. Wrictam A. Hamor, an assistant director of the Mellon Institute of Industrial Research, Pittsburgh, has been given the honorary degree of doctor of laws of the University of Miami.

THE Bristol, Clifton and West of England Zoological Society has agreed to provide funds for a research scholarship in vertebrate zoology tenable at the University of Bristol at the rate of $£ 300$ for three years. Many university scholarships and fellowships in the fields of physics, chemistry and related subjects are now being financed through industrial sources, and the establishment of this scholarship in the biological field is a most welcome one.

A Polarographic Discussion Panel, having as its objects the holding and the sponsoring of informal discussions on the subject of polarography as applied to chemical analysis, has been formed by the Physical Methods Group of the Society of Public Analysts and Other Analytical Chemists. Plans are in hand to arrange a first meeting in London during April. Particulars may be obtained from the honorary secretary, Mr. J. T. Stock, Chemistry Department, L.C.C. Norwood Technical Institute, Knight's Hill, London, S.E.27.

MAJOR John A. Hunt asks us to state that inquiries in connexion with the report on the Survey of British Somaliland (see Nature, 158, 511; 1946) should be addressed to the Secretary to the Government, Hargeisa, British Somaliland, via Aden; and not Burao as indicated in the bibliographic reference.

Erratum.--In the communication entitled "Constitution of Strychnine and its Relation to Cinchonine" by Sir Robert Robinson in Nature of February 22, p. 263, the bond from the quinoline nucleus should be attached to the 4-position and not to the 3-position as printed. 